\title{
SURVEY OF DEOXYNIVALENOL, DIACETOXYSCIRPENOL, AND T2 TOXIN IN POPCORN HYBRIDS PLANTED IN THE STATE OF SÃO PAULO AND IN POPCORN COMMERCIALIZED IN THE CITY OF CAMPINAS, SP'
}

\author{
Adriana de Queiroz OLIVEIRA², Lucia Maria Valente SOARES ${ }^{2, *}$, Eduardo SAWAZAKI ${ }^{3}$
}

\begin{abstract}
SUMMARY
The incidence of the trichothecenes deoxynivalenol (DON), diacetoxyscirpenol (DAS), and T2 toxin (T2) in popcorn was investigated in 90 samples, belonging to 2 commercial and 28 experimental hybrids planted at experimental stations of the Agronomic Institute of Campinas at the locations of Campinas, Mococa, and Capão Bonito, and in 15 samples of popcorn, 9 branded and 6 unbranded, acquired from commercial outlets in the city of Campinas, SP. The samples were analyzed by gas chromatography with flame ionization detector combined with an alumina:carbon cleanup column. The detection limits were $30 \mathrm{ng} / \mathrm{g}$ for DON, 50ng/g for DAS, and 40ng/g for T2. Five samples were contaminated with DON, four of them commercial and one from an experimental cultivar. The level of contamination in the commercial samples ranged from 30 to $40 \mathrm{ng} / \mathrm{g}$. The sample from the experimental cultivar contained $770 \mathrm{ng} / \mathrm{g}$ DON. DAS and T2 were not detected in any of the popcorn samples analyzed.
\end{abstract}

Keywords: mycotoxins; trichothecenes; deoxynivalenol; popcorn.

\section{RESUMO}

LEVANTAMENTO DA INCIDÊNCIA DE DESOXINIVALENOL, DIACETOXISCIRPENOL E TOXINA T2 EM HÍBRIDOS DE MILHO PIPOCA PLANTADOS NO ESTADO DE SÃO PAULO E EM MILHO PIPOCA COMERCIALIZADO NA CIDADE DE CAMPINAS, SP. A incidência de tricotecenos desoxinivelenol, diacetoxiscirpenol e toxina T2 em milho pipoca foi avaliada em 90 amostras, pertencentes a 2 híbridos comerciais e 28 experimentais, plantados em Estações Experimentais de Instituto Agronômico (Campinas, Mococa e Capão Bonito) e em 15 amostras de milho pipoca, sendo 9 de marcas comerciais e 6 a granel, adquiridas em estabelecimentos comerciais da cidade de Campinas. As amostras foram analisadas por cromatografia gasosa com deteç̧ão por ionização em chama combinada com uma coluna de limpeza de alumina:carvão. Os limites de detecção foram $30 \mathrm{ng} / \mathrm{g}$ para o DON, $50 \mathrm{ng} / \mathrm{g}$ para o DAS e $40 \mathrm{ng} / \mathrm{g}$ para a T2. Cinco amostras estavam contaminadas com DON, sendo quatro de procedência comercial e uma originária de estação experimental. O nível de contaminação nas amostras comerciais variou entre 30 e $40 \mathrm{ng} / \mathrm{g}$. A amostra proveniente da estação experimental estava contaminada com $770 \mathrm{ng} / \mathrm{g}$ de DON. Não foram detectados DAS e T2 nas amostras de milho pipoca analisadas neste trabalho.

Palavras-chave: micotoxinas; tricotecenos; desoxinivalenol; milho pipoca.

\section{1 - INTRODUCTION}

Trichothecenes are secondary metabolites produced by species of Fusarium, Myrothecium, Tricothecium,

\footnotetext{
${ }^{1}$ Recebido para publicação em 29/03/01. Aceito para publicação em 20/09/01.

${ }_{2}^{2}$ Faculdade de Engenharia de Alimentos, Universidade Estadual de Campinas, Caixa Postal 6121, CEP 13081-970 Campinas, S.P. ${ }^{3}$ Instituto Agronômico de Campinas, Caixa Postal 28, CEP 13001970, Campinas, SP. E-mail: valente@fea.unicamp.br

${ }^{*}$ A quem a correspondência deve ser enviada.
}

Stachybotrys, and Verticimonosporium. Over a hundred trichothecenes have been identified in the laboratory, but only about a dozen of these compounds have been found under natural conditions [11, 28]. Trichothecenes are classified according to their chemical structures, based on a ring system denominated 12, 13-epoxytrichothec9 -ene with several possible functional groups attached. Deoxynivalenol (DON) and nivalenol (NIV) are the most frequently studied trichothecenes and diacetoxyscirpenol (DAS) and toxin T2 (T2) are the most toxic among the non-cyclic compounds of the family $[16,19]$. DON is the trichothecene most frequently found in wheat produced in Germany, New Zealand, United States, Canada and Argentina [16].

The trichothecenes toxic effects are emesis, necrotic angina, diarrhea, anorexia, hematological changes, neurological alterations, destruction of the bone marrow, and generalized hemorrhages in some cases followed by death $[22,23,28]$.

The incidence of trichothecenes in cereals is worldwide and it has been reviewed [21, 24]. So far all types of cereals were found contaminated with trichothecenes [13]. All 25 samples of corn and all 10 samples of wheat collected during 1989 in China contained DON and $80 \%$ contained NIV [12]. During the years of 1979 , 1980 and $1982,20 \%$ of the 802 samples of wheat and of the 516 samples of oats analyzed in Germany were contaminated with one or more trichothecenes [26]. DON, NIV, and DAS have also been reported in 11,6 and 13 out of 20 samples, respectively, of corn analyzed in New Zealand [7]. In the U.S., $66 \%$ of the 92 samples of corn analyzed during 1984 and $30 \%$ of the 106 samples of corn analyzed during 1985 contained DON [29]. DON was also found in $13 \%$ out of 32 samples of barley and in $34 \%$ out 32 samples of oats, examined in Sweden in 1982 and in $79 \%$ out of 14 samples of wheat and in $14 \%$ of 14 samples of barley samples analyzed in the same country in 1984 [15]. DON, NIV and other trichothecenes were reported in barley (in 39 samples, 35 contained DON) and corn (in 46 samples, 30 contained DON) in Korea in 1990-1991 [9]. DON was found in all but one of the 77 samples of corn examined in Austria during 1984 [14]. In Argentina, half of 1056 samples of wheat originated from the harvests of 1985 to 1992 were found contaminated with DON [17]. The maximum values of DON found by all the mentioned surveys ranged from 1.05 to $18.00 \mu \mathrm{g} / \mathrm{g}$. Although DON has been the trichothecene most often reported in the literature as involved with the contamination of cereals, other trichothecenes such as T-2 toxin, HT-2 toxin, DAS, and NIV have been found in cereals in several parts of the world such as Argentina, Brazil, Canada, China, Finland, Japan, 
Korea, New Zealand, and U.S. [1, 5, 6, 9, 10, 17, 25]. Researchers started only recently to look for other trichothecenes due to the new commercial availability of standards and reports of the presence of 4-acetylnivalenol, 4, 15 diacetylnivalenol, 3-acetyl deoxinivalenol, 15-acetyldeoxynivalenol, 15-monoacetoxyscirpenol, isoneosolaniol and neosolaniol in cereals can now be found in the literature $[1,6,9,17]$.

Very little is known about the occurrence of trichothecenes in Brazilian foods. SABINO et al. [20] searched for DON in 70 samples of wheat and in 50 samples of corn by a thin-layer chromatography method. Only two samples contained DON at a level of $0.18 \mu \mathrm{g} / \mathrm{g}$. FURLONG et al. [4] analyzed 20 samples of wheat from experimental plots located in the state of São Paulo and found DON in 4 samples $(0.47-0.59 \mu \mathrm{g} / \mathrm{g})$, NIV in 3 samples $(0.16-0.40 \mu \mathrm{g} / \mathrm{g}), \mathrm{T}-2$ in 2 samples $(0.40-0.80 \mu \mathrm{g} / \mathrm{g})$, and DAS in one sample $(0.60 \mu \mathrm{g} / \mathrm{g})$. Also FURLONG et al. [5] examined 18 wheat samples from silos located in the state of Rio Grande do Sul (12 Brazilian, 4 Argentinian, and 2 Uruguayan) and three of the samples were contaminated with DON (1 sample, $0.40 \mu \mathrm{g} / \mathrm{g}$ ), DAS (1 sample, $0.30 \mu \mathrm{g} / \mathrm{g}$ ), T2 (2 samples, 0.35 and $0.36 \mu \mathrm{g} / \mathrm{g}$ ), and T-2 tetraol (1 sample, $1.68 \mu \mathrm{g} / \mathrm{g}$ ).

The present work aimed at evaluating the incidence of DON, DAS and T2 in samples of popcorn planted at experimental fields in the State of São Paulo and in popcorn commercialized within the city of Campinas, SP. This type of corn was chosen because it is consumed by persons of all ages and because it is a special favorite among children.

\section{2 - MATERIAL E METHODS}

\section{1 - Samples}

Ninety samples, belonging to 28 experimental popcorn hybrids and 2 commercial popcorn hybrids were harvested at the Experimental Stations of Campinas, Mococa, and Capão Bonito (Agronomic Institute of Campinas) during the growing season of $1998 / 1999$. The plots had 5 plants per $\mathrm{m}^{2}$ planted in four 5 meter rows with $0.9 \mathrm{~m}$ between rows. All ears were harvested in the two central rows of each plot. The kernels were shelled and combined. The samples were homogenized and reduced by quartering or riffling to $500 \mathrm{~g}$. The samples were kept in plastic bags at $-18^{\circ} \mathrm{C}$ until analysis when the grain was ground to 80 mesh.

Fifteen samples of popcorn (500g each) sold at markets and supermarkets in the city of Campinas, state of São Paulo, were brought to the lab and kept at $-18^{\circ} \mathrm{C}$ until analysis. Before analysis the samples were ground to pass an 80 mesh sieve and transferred to glass containers.

\section{2 - Standards}

Individual trichothecenes stock solutions were prepared - DON, T2 e DAS - (Sigma, U.S.A.) weighing $1 \mathrm{mg}$ of each toxin and dissolving in $10 \mathrm{~mL}$ benzene, according to FURLONG \& SOARES [3], to the concen- tration of $100 \mu \mathrm{g} / \mathrm{mL}$. The working solutions were prepared by diluting the stock solutions to $40 \mu \mathrm{g} / \mathrm{mL}$. All standard solutions were stored in ambar flasks with Teflon seals and kept at $-18^{\circ} \mathrm{C}$ when not in use.

Methyl arachidate (Poly Science, U.S.A.) was used as an internal standard for the gas chromatography. A stock solution was prepared weighing $5 \mathrm{mg}$ of the ester, dissolving it in $10 \mathrm{~mL} \mathrm{n}$-hexane. A working solution was obtained by diluting it with $\mathrm{n}$-hexane to $100 \mu \mathrm{g} / \mathrm{mL}$.

\section{3 - Determination of trichothecenes}

The samples were analyzed by the method developed by FURLONG, SOARES [3] with the additional cleanup step with a alumina:carbon column described by ROMER [18]. The combination of the two systems and its application to corn had been evaluated and described elsewhere (OLIVEIRA, SOARES, submitted). The procedure was used as follows: Extract a $50 \mathrm{~g}$ of sample with $270 \mathrm{~mL}$ methanol and $30 \mathrm{~mL} 4 \%$ potassium chloride for 5 minutes in a blender. Filter through fluted qualitative filter paper. Take a $150 \mathrm{~mL}$ aliquot and transfer to a beaker. Add $150 \mathrm{~mL}$ ammonium sulfate solution and filter through another fluted qualitative filter paper. Take a $150 \mathrm{~mL}$ aliquot and transfer to a separatory funnel and add $150 \mathrm{~mL}$ water. Add $15 \mathrm{~mL}$ dichloromethane and shake it slowly during 3 minutes. Allow layers to separate for at least 10 minutes and collect the dichloromethane layer. Repeat the extraction with another $15 \mathrm{~mL}$ dichloromethane and add the second dichloromethane layer to the first. Leave the flask containing the dicloromethane extract for 20 seconds in an ultrasonic bath for complete homogenizing. Take $15 \mathrm{~mL}$ aliquot and let it dry over a water bath at $50^{\circ} \mathrm{C}$. Dissolve the dried extract with less than $1 \mathrm{~mL}$ acetonitrile:water $(84: 16)$ and transfer it to an alumina:carbon (2.3:1.9) column. Prepare the column (about $1.5 \mathrm{~cm}$ i.d.) by dry filling it with a layer of alumina to a height of $1.1 \mathrm{~cm}$ followed by active carbon (100 400 mesh, Sigma) up to $4.0 \mathrm{~cm}$. Insert plugs of glass wool on the top and bottom of the column. Finally condition the column by passing $15 \mathrm{~mL}$ acetonitrile:water (84:16) through it before applying the sample. Elute the trichothecenes with $40 \mathrm{~mL}$ acetonitrile:water $(84: 16)$ at a $1 \mathrm{~mL} /$ min flow. Concetrate the eluate over a water-bath at $80^{\circ} \mathrm{C}$, and transfer it to a small $4 \mathrm{~mL}$ vial before drying it completely. Add to the dried extract $1 \mathrm{~mL}$ of $1.5 \mathrm{mg} / \mathrm{mL}$ pyridine in toluene:acetonitrile (95:5) and $200 \mu \mathrm{L}$ de TFAA (trifluoroacetic acid, Sigma). Leave the flask over a waterbath at $60^{\circ} \mathrm{C}$ for 60 minutes. Allow the reaction mixture to cool at room temperature and add $1 \mathrm{~mL}$ of $5 \% \mathrm{KH}_{2} \mathrm{PO}_{4}$ and mix it for 30 seconds in an ultrasonic bath. Take an $850 \mu \mathrm{L}$ aliquot and transfer to a second flask containing $1 \mathrm{~mL} 5 \% \mathrm{KH}_{2} \mathrm{PO}_{4}$ and shake again for 30 seconds in an ultrasonic bath. Take an aliquot of $650 \mu \mathrm{L}$ and transfer it to another flask and add about $3 \mu \mathrm{g}$ of the internal standard. Dry under at $50^{\circ} \mathrm{C}$ under a light stream of $\mathrm{N}_{2}$. Dissolve the residue with $100 \mu \mathrm{L}$-hexane and inject about $1 \mu \mathrm{L}$ into the gas chromatograph.

The gas chromatograph employed was a model Star 3400cx, Varian (U.S.A.), with injector model 1078, a FID detector, and a DB-1701 capillary column (JW Scientific) 
with $15 \mathrm{~m}$, an internal diameter of $0.32 \mathrm{~mm}$ and $0.25 \mu \mathrm{m}$ film thickness. The chromatographic conditions employed were: injector temperature $\left(275^{\circ} \mathrm{C}\right)$, detector temperature $\left(300^{\circ} \mathrm{C}\right)$, column oven program $\left(100^{\circ} \mathrm{C} / 1 \mathrm{~min}, 6^{\circ} \mathrm{C} / \mathrm{min}\right.$ until $\left.220^{\circ} \mathrm{C} / 20 \mathrm{~min}\right)$, hydrogen flow $(3.6 \mathrm{~mL} / \mathrm{min})$. Splitless injection was used and the valve purge time was set at $0.75 \mathrm{~min}$.

\section{4 - Analytical quality control}

The samples were analyzed in 12 series of 8 and one of 9. Each series included one spiked sample for recovery test, fortified with $0.50 \mu \mathrm{g} / \mathrm{g}$ DON, DAS and T2. The results of the contaminated samples were corrected for the recovery of the test sample belonging to the series. The duplicates of each contaminated sample were analyzed on different days.

\section{5 - Confirmation of identity}

For confirmation of identity the presumptive positive samples were submitted to derivatization reactions as described by FURLONG, SOARES [3].

\section{3 - RESULTS AND DISCUSSION}

The detection limits of the method employed were determined as the signal three times greater than the noise and they were $30 \mathrm{ng} / \mathrm{g}$ for DON, $50 \mathrm{ng} / \mathrm{g}$ for DAS, and $40 \mathrm{ng} / \mathrm{g}$ for T2. The quantification limits were taken as 5 times the detection limit for each trichothecene. Five of the samples from the 105 analyzed were contaminated with DON. Four samples of commercial popcorn contained DON in the range of $32-40 \mathrm{ng} / \mathrm{g}$. These values were close to the method detection limit for DON and bellow the quantification limit and so they could not be confirmed by derivatization reactions. One sample of popcorn from one of the experimental stations, belonging to an experimental hybrid, contained $770 \mathrm{ng} / \mathrm{g}$ DON (Figure 1) and the higher toxin level allowed it to be confirmed by the derivatization reactions. No specific reason can be ascribed on why such a high value appeared among so many negative (non detected) samples. No mycological examination of the samples was conducted, and contamination of food commodities by mycotoxins are known to be discontinuous, seasonal and subject to local factors such as insect attacks. Only further testing would show if this particular hybrid has any special susceptibility to trichothecene producing Fusarium spp.

The level of DON found in the sample from the experimental station is bellow the maximum limit of $1000 \mathrm{ng} / \mathrm{g}$ advised the Food and Drug Administration, U.S.A., for corn flour, corn grits or corn germ destined to human consumption [27]. In Brazil we do not have a recommended level for DON in foods or animal feed. Recently the Joint Expert Committee on Food Additives, FAO/ $\mathrm{UN}$, issued a provisional maximum tolerable daily intake for DON of $1 \mu \mathrm{g} / \mathrm{kg}$ b.w. per day [2]. Dry corn consumption, which would include popcorn, is low in Brazil and it amounts to $3.5 \mathrm{~g} / \mathrm{day}$ [8]. This shows the little or negligible impact the low incidence and low levels of DON found in popcorn by the present survey would have on the population health in general.

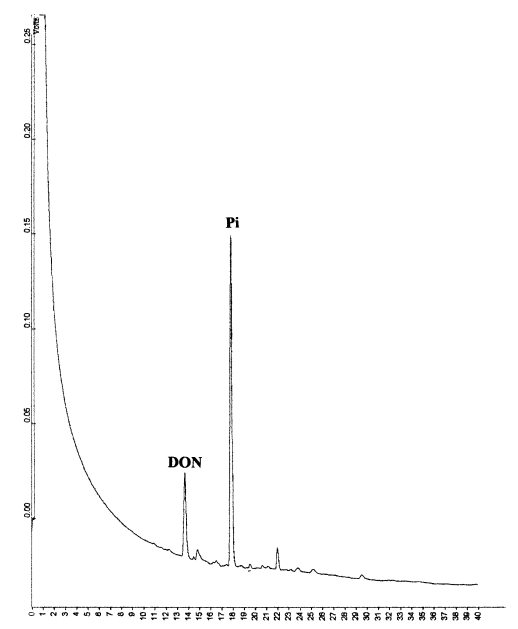

FIGURE 1. Gas chromatogram of a popcorn sample naturally contaminated with DON (770ng/g). PI indicates the internal standard (Methyl arachidate).

\section{4 - CONCLUSIONS}

The results from the present work indicate that the incidence of tricothecenes in popcorn planted at experimental fields located on three corn producing areas of the state of São Paulo is low. The survey conducted on commercial samples indicates there is currently no risk for the population in the ingestion of popcorn in terms of the trichothecenes investigated. However, as mycotoxins are subjected to year-to-year variability due to their dependence on weather conditions, it is advisable to repeat the survey periodically. Imported popcorn, on another hand, should be routinely monitored because some of the countries exporting it to Brazil have well documented problems with trichothecenes.

\section{5 - REFERENCES}

[1] CHU, F.M.; LI, G.Y. Simultaneous occurrence of fumonisin $B_{1}$ and other mycotoxins in moldy corn collected from people's Republic of China in regions with high incidence of esophageal cancer. Applied and Environmental Microbiology, v. 60, n. 3, p. 847-852, 1994.

[2] FOOD AND AGRICULTURE ORGANIZATION. Report of the Joint FAO/WHO Expert Committee on Food Additives, Fifty-sixth meeting, Geneva, 6-15 February 2001.

[3] FURLONG, E.B., SOARES, L. M. V. Gas chromatographic method for quantification and confirmation of trichothecenes in wheat. Journal of the AOAC International, v. 78, n. 2, p. 386-390, 1995.

[4] FURLONG, E.B., SOARES, L. M. V., LASCA, C. C., KOHARA, E. Y. Mycotoxins and fungi in wheat harvested during 1990 in test plots in the state of São Paulo, Brazil. Mycopathology, v. 131, p. $185-190,1995$.

[5] FURLONG, E. B., SOARES, L.M. V., LASCA, C. C., KOHARA, $E$. Y. Mycotoxins and fungi in wheat stored in elevators in the state of Rio Grande do Sul, Brazil. Food Additives and Contaminants, v. 12, n. 5, p. 683-688, 1995.

[6] HIETANIEMI, V.; KUMPULAINEN, J. Contents of Fusarium toxins in Finnish and imported grains and feeds. Food Additives and Contaminants, v. 8, n. 2, p. 171-182, 1991. 
[7] HUSSAIN, H.M., FRANICH, R.A., BAXTER, M., ANDREW, I.G. Naturally occurring Fusarium toxins in New Zealand maize. Food Additives and Contaminants, v. 6, p. 4958,1989 .

[8] INSTITUTO BRASILEIRO DE GEOGRAFIA E ESTATÍSTICA. Pesquisa de Orçamentos Familiares, [http:// www.sidra.ibge.gov.br/bda/tabela/listabl.asp ?e=1\&c=419, 13/082001], 2001.

[9] KIM, J.C., KANG, H.J., LEE, D.H., LEE, Y.W., YOSHIZAWA, T. Natural occurrence of Fusarium mycotoxins in barley and corn in Korea. Applied and Environmental Microbiology, v. 59, p. 3798-3802, 1993.

[10] LAUREN, D.R.; GREENHALGH, R. Simultaneous analysis of nivalenol and deoxynivalenol in cerals by liquid chromatography. Journal of the Association Official Analytical Chemists, v. 70, n.3, p. 479-483, 1987.

[11] LANGSETH, W., RUNDBERGET, T. Instrumental methods for determination of nonmacrocyclic trichothecenes in cereals, foodstuffs and cultures. Journal of Chromatography A, v. 815, , n. 1, p. 103-121, 1998.

[12] LUO, Y., YOSHIZAWA, T., YANG, J.S., ZHANG, S.Y., ZHANG, B.J. A survey of the occurrence of Fusarium mycotoxins (trichothecenes, zearalenone, and fusarochromanone) in corn and wheat samples from Shaanxi and Shanxi Provinces, China. Mycotoxin Research, v. 8, p. 85-91, 1992.

[13] MILLER, J.D. Fungi and mycotoxins in grain: Implications for stored product research. Journal of Stored Product Research, v. 31, n. 1, p. 1-16, 1995.

[14] NOONPUDGEE, C. Untersuchungen über das Vorkommen fon Zearalenon un Desoxynivalenol in österreichischen Körnermaisproben. Ernährung, v. 9, p. 850-854, 1985.

[15] PETTERSSON, H., KIESSLING, K.H., SANDHOLM, K. Occurrence of the trichothecene mycotoxin deoxynivalenol in Swedish-grown cereals. Swedish Journal of Agricultural Research, v. 16, p. 179-182, 1986.

[16] PLACINTA, C. M., D'MELLO, J. P. F., MACDONALD, A. M.C. $A$ review of worldwide contamination of cereal grains and animal feed with Fusarium mycotoxins. Animal Feed Science and Technology, v. 78, n. 1, p. 21-37, 1999.

[17] QUIROGA, N., RESNIK, S., PACIN, A., MARTINEZ, E., PAGANO, A., RICCOBENE, I., NEIRA, S. Natural occurrence of trichothecenes and zearalenone in Argentine wheat. Food Control, v. 6, p. 201-201, 1995.

[18] ROMER, T. R. Use of small charcoal/alumina clean-up columns in determination of trichothecene mycotoxins in foods and feeds. J. Assoc. Off. Anal. Chem., v. 69, n. 4, p. 699703, 1986.
[19] ROMER, T.R.; BOLING, T.M.; MACDONALD, J.L. Gas-liquid chromatography determination of T-2 toxin and diacetoxyscirpenol in corn and mixed feeds. J. Assoc. Off. Anal. Chem., v. 61, n. 4, p. 801-808, 1978.

[20] SABINO, M., ICHIKAWA, A. H., INOMATA, E. I., LAMARDO, L. C.A. Determinação de desoxinivalenol em trigo e milho em grão por cromatografia em camada delgada. Revista do Instituto Adolfo Lutz, v. 49, p. 155-159, 1989.

[21] SCOTT, P.M. The natural occurrence of trichothecenes. In: BEASLEY, V.R. (Ed.) Trichothecene mycotoxicosis: Pathophysiologic effects. Boca Raton: CRC Press, 1989. p. 1-26.

[22] SCOTT, P. M., KANHERE, S. R. Comparison of column phases for separation of derivatezed trichothecenes by capillary gas chromathography. Journal of Chromatography, v. 368, n. 2, p. 374-380, 1986.

[23] SNYDER, A. P. Qualitative, quantitative and technological aspects of the trichothecene mycotoxins. Journal of Food Protection, v. 49, n. 7, p. 544-569, 1986.

[24] TANAKA, T., HASEGAWA, A., YAMAMMOTO, S., LEE, U.S., SUGIURA, Y., UENO, Y. Worldwide contamination of cereals by the Fusarium mycotoxins nivalenol, deoxynivalenol, and zearalenone. 1 . Survey of 19 countries. Journal of Agricultural and Food Chemistry, v. 36, p. 979-983, 1988.

[25] TANAKA, T; YONEDA, A.; INOUE, S.; SUGIURA, Y.; UENO, $Y$. Simultaneous determination of trichothecene mycotoxins and zearalenone in cereals by gas chromatography-mass spectrometry. Journal of Chromatography A, v. 882, n. 1, p. 23-28, 2000.

[26] THALMANN, A., MATZENAUER, S., GRUBER-SCHLEY, S. Untersuchungen über das Vorkommen von Fusarientoxinen in Getreide. Berichte über Landwirtschaft, v. 2, p. 257272, 1985.

[27] VAN EGMOND, H.P. Current situation on regulations for mycotoxins. Overview of tolerances and status of standard methods of sampling and analysis. Food Additives and Contaminants, v. 6, n. 2, p. 139-188, 1989.

[28] UENO, Y. Trichothecenes as Environmental Toxicants. Reviews in Environmental Toxicology 2, Amsterdan, p. 303-341, 1986.

[29] WOOD, G.E., CARTER JR., L. Limited survey of deoxynivalenol in wheat and corn in the United States. J. Assoc. Off. Anal. Chem., v. 72, p. 38-40, 1989.

\section{6 - ACKNOWLEDGEMENT}

The first author, A.Q. Oliveira, thanks Fundação de Amparo à Pesquisa do Estado de São Paulo - FAPESP for the graduate scholarship granted. 